\title{
Stability and yield of rice (Oryza sativa L.) genotypes at three agro ecological zones of South west Nigeria
}

\author{
Osekita Oluwatoyin Sunday* \\ Crop improvement unit, Department of Plant Science and Biotechnology, Adekunle Ajasin University, Akungba Akoko, Nigeria
}

${ }^{*}$ Corresponding Author
Osekita Oluwatoyin Sunday

Article History

Received: 06.08.2019

Accepted: 27.08 .2019

Published: 30.09 .2019

\begin{abstract}
This study was carried out to evaluate the yield performance and stability of rice genotypes across three environments representing different agro-ecological zones of southwest Nigeria. Genetic variation and yield stability assessment for components of yield and morphological traits among sixteen lowland rice genotypes were investigated at three locations namely Akungba, Akure and Okitipupa during the rainy seasons of 2013, 2014 and 2015. The experiment was conducted in a randomized complete block design (RCBD) replicated three times, a plot size of $10 \mathrm{~m} \times 10 \mathrm{~m}$ and spacing of $20 \mathrm{~cm} \times 20 \mathrm{~cm}$ was adopted to make a total plant density of 250,000 stands/ha. Cultural operations which include weeding, fertilizer and pesticide applications were carried out as appropriate. Data were collected on plant height, number of tillers per hill, effective tillers, tiller without panicle, flag leaf length, panicle length, panicle weight, number of grains per panicle, number of spikelets per panicle, one thousand grains weight, grain length, grain width, number of days to panicle initiation, number of days to maturity and grain yield per hill. WITA 4 was highly unstable and poor yielding whereas FARO 57, NL 9, MRQ 74 and WITA 4 are highly stable but were lower in yield. MR 269 was the least stable genotype.
\end{abstract}

Keywords: Variability, genotypes, stability, agro-ecology, yield.

\section{INTRODUCTION}

Rice belongs to a group of extremely earliest grasses showing more genetic and morphological diversity than virtually any other cultivated crop. It is basically a terrestrial plant adapted to an aquatic habitat [1]. The major challenge of rice research and development in the world is finding means to produce enough to meet the need of the fast growing population with particular reference to developing nations such as Nigeria. Rice as an annual plant will thrive well in a wide range of soils such as saline, alkaline and acidsulphur soil [2, 3]. It is adapted to different environments depending upon water availability (IRRI, 2003). Rice is usually grown as an annual plant but can survive as a perennial in the tropics. There is the lowland rice type which is drought prone, favour medium depth and water logged condition and its production capacity far outweighs the upland types [1]. Yield in rice is an important trait that is driven by many genes hence it is polygenic in nature. Therefore, grain yield is a complex trait, quantitative in nature and a combined task of a number of component traits. Therefore, selection for yield per se may not be much paying except other yield attributing traits are taken into consideration [4]. Stability in common usage connotes consistency in performance that would mean minimum variation among environments for a particular genotype [5]. Successful cultivation of any given crop species or cultivar in an agro-climatic region depends on its adaptability and yield stability. Adaptability or stability of a cultivar often associates with physiological, morphological and phenological mechanisms. The stability with which a plant breeder is concerned implies stability in those aspects of phenotype which are important economically, such as yield and quality. The purpose of this work is to evaluate the yield performance and stability of rice genotypes across three agro-ecological zones of southwest Nigeria.

\section{Materials and Methods}

Rice genotypes used for this research were obtained from Malaysian Agricultural Research and Development Institute (MARDI) Seberang Perai, Malaysia and Africa Rice Ibadan, Oyo State Nigeria. The field experiment was carried out between June and October 2013, 2014 and 2015 at three locations; Akungba, Akure and Okitipupa representing three agro-ecological zones of southwest Nigeria. The rice seeds were raised in the nursery for about three weeks before the seedlings were transplanted in the open field at a spacing of $20 \mathrm{~cm} \times 20 \mathrm{~cm}$ within and between rows. The land area used for the research is $2500 \mathrm{~m}^{2}$ partitioned into

Copyright @ 2019: This is an open-access article distributed under the terms of the Creative Commons Attribution license which permits unrestricted use, distribution, and reproduction in any medium for non commercial use (NonCommercial, or CC-BY-NC) provided the original author and source are credited. 
blocks of three with each block having a subplot size $10 \mathrm{~m} \times 10 \mathrm{~m}$ arranged in a randomized complete block design with a total plant density of 250,000 stands/ha. Cultural operations such as weed control (2, 4-D Dimethylamine), insecticide application Cyperforce (Cypermetrin $10 \%$ E.C), and fertilizer application: NPK 15:15:15, Urea 46\% N were carried out as at when necessary.

\section{Data collection}

Data were collected on the following agronomic and quantitative traits for measurements of stability and yield potentials of the rice genotypes. These include; plant height, number of tillers per hill, effective tillers, tiller without panicle, flag leaf length, panicle length, panicle weight, number of grains per panicle, number of spikelets per panicle, one thousand grains weight, grain length, grain width, number of days to panicle initiation, number of days to maturity and grain yield per hill.

\section{Data analysis}

Plant breeding tools (PB Tools) version 1.3 and Minitab 17 was used to analyze data collected for estimate of variability and Joint Regression Analysis according to Finlay and Wilkinson [6] procedure for yield stability was adopted.

\section{RESULtS AND Discussion}

The combined mean squares and coefficient of variation (CV) for fourteen agronomic and yield component traits of sixteen lowland rice genotypes evaluated in five environments were presented in Table 1. The analysis of variance for combined environments, the effect of replication, genotypes main effect and genotype by environment interaction were all highly significant $(P<$ $0.01)$ for the fourteen traits evaluated. The grand mean values for plant height is $(120.6 \mathrm{~cm})$, number of tillers (17.6), effective tillers (15.7), flag leaf length $(27.1 \mathrm{~cm})$, panicle length $(24.9 \mathrm{~cm})$, panicle weight $(4.6 \mathrm{~g})$, number of grains per panicle $(148.8)$, number of spikelet (11.5), one thousand grain weight $(26.1 \mathrm{~g})$, grain length $(0.9)$, grain width $(0.3)$, number of days to flowering (88.0), number of days to maturity (118.0) and grain yield per hill $(55.5 \mathrm{~g})$. The coefficient of variation for the traits were generally low, it ranged from $0.0 \%$ in grain width to $17.4 \%$ in number of tillers/hill. The contributions of genotype $x$ environment interaction (GEI) percentage proportion to total variation on quantitative traits measured indicated that plant height had $(3.10 \%)$, number of tillers per hill $(6.35 \%)$, effective tillers per hill $(5.35 \%)$, flag leaf length $(7.33 \%)$, panicle length $(4.48 \%)$, panicle weight $(5.33 \%)$, number of grains per panicle $(8.18 \%)$, number of spikelets per panicle $(4.60 \%)$, one thousand grains weight $(4.13 \%)$, grain length $(23.39 \%)$, grain width $(58.82 \%)$, number of days to flowering $(2.21 \%)$, number of days to maturity $(2.19 \%)$ and grain yield per hill $(4.89 \%)$. The significant variations observed from the numerous traits and interactions of genotype $\mathrm{x}$ environment is a prerequisite for achieving the goal of breeding high yielding and better quality lines for release to farmers. The sufficient amount of variability noted in both agronomic and yield component traits in this study was corroborated in the study conducted by Akinwale et al., [7].

The result of Mean grain yield for sixteen lowland rice genotypes studied in five environments were presented in Table 2 which indicated that performance of rice genotypes were different at different testing environments, as a result confirming the existence of genotype $x$ environment interaction. The variation may be due to genotype and environment factors because different genotypes won the first, second and third in different environments, whereas the best performed genotype across the five environments was BW 348-1.

\section{Regression coefficient as a measure of stability}

According to Finlay-Wilkinson [6] when regression coefficients approximate 1.0, it is an indication of average stability and must always be associated and interpreted with the genotype mean yield to determine desirability. From the result of Finlay-Wilkinson stability analysis and ranking of grain yield across test environments (Table 3), six out of the sixteen lowland rice genotypes showed average stability with average mean yields. The genotypes are MRQ 76, MRQ 74, MR 220, FARO 57, WITA 4 and NL 11. Also, BW 348-1, IRRI 154, NL 34, NL 25 and NL 30 had very high mean yield were unstable. The stability analysis of the rice genotypes using GGE biplot displayed the genotype main effect $(G)$ and the genotype $x$ environment interaction (GEI), which are the most important sources of variation for cultivar evaluation in a multi-environment trials [7]. This biplot showed stable and unstable, adaptable and unadaptable as well as high and low yielding genotypes. NL 25 and NL 19 were high yielding and are adapted to Akungba and Akure respectively. The genotype that won across the locations was BW 348-1which was closely followed by IRRI 154, unfortunately, they are unstable. NL 19 that is very close to zero on the axis of the PC2 won in Okitipupa and was relatively stable, whereas, NL 34 and NL 25 won in Akungba Akoko and are stable. 
Osekita Oluwatoyin Sunday.; South Asian Res J Bio Appl Biosci; Vol-1, Iss- 2 (Aug-Sep, 2019): 38-42

Table-1: Mean squares from analysis of variance (ANOVA) for fourteen agronomic traits of sixteen lowland rice genotypes evaluated in five environments.

\begin{tabular}{|c|c|c|c|c|c|c|c|c|}
\hline $\begin{array}{l}\text { Source of } \\
\text { variation }\end{array}$ & $\begin{array}{l}\text { Degree of } \\
\text { freedom }\end{array}$ & $\begin{array}{l}\text { Plant } \\
\text { height }(\mathrm{cm})\end{array}$ & $\begin{array}{l}\text { Number } \\
\text { of tillers }\end{array}$ & $\begin{array}{l}\text { Effective } \\
\text { tillers/ } \\
\text { panicle }\end{array}$ & $\begin{array}{l}\text { Flag leaf } \\
\text { length } \\
(\mathrm{cm})\end{array}$ & $\begin{array}{l}\text { Panicle } \\
\text { Length } \\
\text { (cm) }\end{array}$ & $\begin{array}{l}\text { Panicle } \\
\text { Weight } \\
\text { (g) }\end{array}$ & $\begin{array}{l}\text { No of } \\
\text { grains / } \\
\text { panicle }\end{array}$ \\
\hline Replication & 2 & $487.0^{* *}$ & $31.4^{* *}$ & $38.1^{* *}$ & $2.4^{\star \star}$ & $1.0^{* \star}$ & 0.09 & $231.5^{\mathrm{ns}}$ \\
\hline Environment & 4 & $4553.0^{* *}$ & $88.1^{* *}$ & $28.7^{* *}$ & $17.8^{* *}$ & $279.8^{* *}$ & $6.0^{* *}$ & $10461.8^{* *}$ \\
\hline Genotypes & 15 & $6646.4^{* *}$ & $109.2^{* \star}$ & $65.0^{* *}$ & $235.5^{\star \star}$ & $111.8^{\star *}$ & $24.8^{* *}$ & $14345.5^{\star *}$ \\
\hline Env * Gen & 60 & $383.6^{* *}$ & $20.9^{* *}$ & $10.8^{* *}$ & $21.0^{* *}$ & $18.7^{* *}$ & $1.8^{* *}$ & $2303.3^{* *}$ \\
\hline Env * Rep & 8 & $168.6^{* *}$ & $60.8^{* *}$ & $46.7^{* *}$ & $2.1^{* *}$ & $2.6^{* \star}$ & $0.2^{* *}$ & 56.0 \\
\hline Gen * Rep & 30 & $74.9^{* *}$ & $9.5^{\star *}$ & $6.6^{\star \star}$ & $4.7^{* *}$ & $1.8^{* *}$ & $0.6^{* *}$ & $488.5^{\star \star}$ \\
\hline Pooled error & 120 & 45.9 & 9.4 & 5.9 & 3.0 & 1.4 & 0.3 & 276.2 \\
\hline CV (\%) & & 5.6 & 17.4 & 15.5 & 6.4 & 4.8 & 11.9 & 11.2 \\
\hline$G \bar{x}$ & & 120.6 & 17.6 & 15.7 & 27.1 & 24.9 & 4.6 & 148.8 \\
\hline $\begin{array}{l}\text { GEI } \\
\text { Proportion } \\
(\%)\end{array}$ & & 3.10 & 6.35 & 5.35 & 7.33 & 4.48 & 5.33 & 8.18 \\
\hline
\end{tabular}

Table-1: Continued.

\begin{tabular}{|c|c|c|c|c|c|c|c|c|}
\hline $\begin{array}{l}\text { Source of } \\
\text { variation }\end{array}$ & $\begin{array}{l}\text { Degree of } \\
\text { freedom }\end{array}$ & $\begin{array}{l}\text { Number of } \\
\text { spikelet/panicle }\end{array}$ & $\begin{array}{l}\text { Thousand } \\
\text { grain weight } \\
\text { (g) }\end{array}$ & $\begin{array}{l}\text { Grain } \\
\text { length } \\
(\mathrm{cm})\end{array}$ & $\begin{array}{l}\text { Grain } \\
\text { width } \\
(\mathrm{cm})\end{array}$ & $\begin{array}{ll}\text { Number } & \text { of } \\
\text { days } & \text { to } \\
\text { flowering } & \\
\end{array}$ & $\begin{array}{ll}\text { Number } & \text { of } \\
\text { days } & \text { to } \\
\text { maturity } & \\
\end{array}$ & $\begin{array}{l}\text { Yield per } \\
\text { hill }(\mathrm{g})\end{array}$ \\
\hline Replication & 2 & $0.8^{* *}$ & 0.1 & $0.04^{* *}$ & $0.001^{* *}$ & $1.3^{\star \star}$ & $1.4^{* *}$ & $49.7^{\star *}$ \\
\hline Environments & 4 & $36.3^{* *}$ & $70.1^{* *}$ & $0.05^{* *}$ & $0.02^{* *}$ & $11.3^{* *}$ & $13.1^{* *}$ & $7026.7^{* *}$ \\
\hline Genotypes & 15 & $57.7^{\star \star}$ & $154.0^{* *}$ & $0.02^{* *}$ & $0.01^{* *}$ & $1105.6^{\star \star}$ & $1112.1^{* \star}$ & $2532.0^{* *}$ \\
\hline Env * Gen & 60 & $4.7^{* \star}$ & $9.9^{* *}$ & $0.04^{* *}$ & $0.002^{* *}$ & $25.3^{* *}$ & $25.3^{* *}$ & $457.4^{* *}$ \\
\hline Env ${ }^{*} \operatorname{Rep}$ & 8 & $1.3^{* *}$ & $2.0^{* *}$ & $0.01^{* *}$ & $0.001^{* *}$ & $0.66^{* *}$ & 0.37 & $31.3^{\star *}$ \\
\hline Gen * Rep & 30 & $0.7^{\star \star}$ & $2.4^{* *}$ & $0.01^{* *}$ & 0.000 & $0.83^{* *}$ & $0.76^{* *}$ & $58.6^{* *}$ \\
\hline Pooled error & 120 & 0.6 & 1.3 & 0.001 & 0.000 & 0.8 & 0.7 & 40.1 \\
\hline CV (\%) & & 6.7 & 4.4 & 3.5 & 0.0 & 1.0 & 0.7 & 11.4 \\
\hline$G \bar{x}$ & & 11.5 & 26.1 & 0.9 & 0.3 & 88.0 & 118.0 & 55.5 \\
\hline $\begin{array}{l}\text { GEl } \\
\text { Proportion (\%) }\end{array}$ & & 4.60 & 4.13 & 23.39 & 58.82 & 2.21 & 2.19 & 4.89 \\
\hline
\end{tabular}

Table -2: Means of grain yield for sixteen lowland rice genotypes studied in five environments

\begin{tabular}{|c|c|c|c|c|c|c|}
\hline Genotypes & $\begin{array}{c}\text { Akungba } \\
2013\end{array}$ & $\begin{array}{c}\text { Akungba } \\
2014\end{array}$ & Akure 2013 & Akure 2014 & Okitipupa 2015 & $\begin{array}{c}\text { Genotype } \\
\text { mean }\end{array}$ \\
\hline MRQ 76 & 3.81 & 3.97 & 14.53 & 14.04 & 17.07 & 10.68 \\
\hline MR 269 & 3.63 & 6.71 & 18.41 & 17.67 & 19.78 & 13.24 \\
\hline MRQ 74 & 4.73 & 10.42 & 14.59 & 14.28 & 13.79 & 11.56 \\
\hline MR 220 & 4.22 & 7.77 & 14.50 & 14.12 & 15.01 & 11.12 \\
\hline MR 263 & 3.45 & 10.80 & 16.60 & 16.07 & 15.27 & 12.44 \\
\hline MR 253 & 3.41 & 14.86 & 18.37 & 17.80 & 14.90 & 13.87 \\
\hline FARO 57 & 9.41 & 11.62 & 14.31 & 14.32 & 14.89 & 12.91 \\
\hline FARO 44 & 4.83 & 8.56 & 16.87 & 16.36 & 17.51 & 12.83 \\
\hline NL 19 & 10.02 & 11.01 & 17.44 & 17.22 & 19.05 & 14.95 \\
\hline WITA 4 & 6.02 & 3.43 & 8.54 & 8.63 & 11.59 & 7.61 \\
\hline BW 348-1 & $\mathbf{2 1 . 7 3}$ & $\mathbf{2 1 . 5 9}$ & $\mathbf{2 0 . 7 9}$ & $\mathbf{2 1 . 2 0}$ & $\mathbf{2 1 . 9 6}$ & 21.45 \\
\hline NL 30 & 13.71 & 14.31 & 13.76 & 14.11 & 14.63 & 14.11 \\
\hline NL 34 & 16.07 & 15.71 & 15.54 & 15.91 & 16.89 & 16.02 \\
\hline IRRI 154 & 17.79 & 18.77 & 18.71 & 19.00 & 19.48 & 18.75 \\
\hline NL 11 & 12.47 & 13.29 & 13.04 & 13.35 & 13.84 & 13.20 \\
\hline NL 25 & 15.82 & 16.20 & 15.52 & 15.89 & 16.47 & 15.98 \\
\hline Environment & 9.44 & 11.81 & 15.72 & 15.62 & 16.38 & 13.80 \\
\hline Mean & & & & & & \\
\hline
\end{tabular}


Table-3: Finlay-Wilkinson Stability analysis and ranking of grain yield across test environments.

\begin{tabular}{|c|c|c|c|c|c|}
\hline Genotypes & Slope & SE & Mean & Yield rank & Stable genotype \\
\hline MRQ 76 & 1.98 & 0.38 & 10.68 & 15 & + \\
\hline MR 269 & 2.42 & 0.29 & 13.24 & 8 & + \\
\hline MRQ 74 & 1.33 & 0.22 & 11.56 & 13 & + \\
\hline MR 220 & 1.63 & 0.08 & 11.12 & 14 & 12 \\
\hline MR 263 & 1.76 & 0.28 & 12.44 & 12 & \\
\hline MR 253 & 1.74 & 0.63 & 13.87 & 7 & + \\
\hline FARO 57 & 0.79 & 0.10 & 12.91 & 10 & \\
\hline FARO 44 & 1.87 & 0.26 & 12.83 & 11 & + \\
\hline NL 19 & 1.30 & 0.27 & 14.95 & 5 & + \\
\hline WITA 4 & 0.93 & 0.74 & 7.61 & 16 & \\
\hline BW 348-1 & -0.05 & 0.15 & 21.45 & 1 & \\
\hline NL 30 & 0.05 & 0.05 & 14.11 & 6 & + \\
\hline NL 34 & 0.03 & 0.09 & 16.02 & 3 & + \\
\hline IRRI 154 & 0.13 & 0.15 & 18.75 & 2 & \\
\hline NL 11 & 0.12 & 0.13 & 13.20 & 9 & \\
\hline NL 25 & -0.01 & 0.06 & 15.98 & 4 & \\
\hline
\end{tabular}

Figure 1 shows the adaptation map for predicted grain yield across test environments, genotype 7 (FARO 57) was adaptable, highly stable and its yield increased steadily across the test environments. The first interaction principal component axis accounted for $71.5 \%$ of the total variation across the test environments.

Figure 2 defines an "ideal" genotype (the centre of the concentric circles) to be a point on the AEA ("absolute stable") in the positive direction and has a vector length equal to the longest vectors of the genotypes on the positive side of AEA ("highest mean performance"). Therefore, genotypes located closer to the 'ideal genotype' are more desirable than others. Thus IRRI 154 (18.75g)and NL $19(14.95 \mathrm{~g})$ were more desirable than BW 348-1 (21.45g) even though it had highest average yield per hill. WITA 4 was the poorest genotype because it was consistently the poorest in terms of average yield. This figure also illustrates the concept regarding stability, the term high stability is only meaningful when associated with mean performance, WITA 4 was highly unstable and poor yielding whereas FARO 57, NL 9, MRQ 74 and WITA 4 are highly stable but were lower in yield. MR 269 was the least stable genotype.

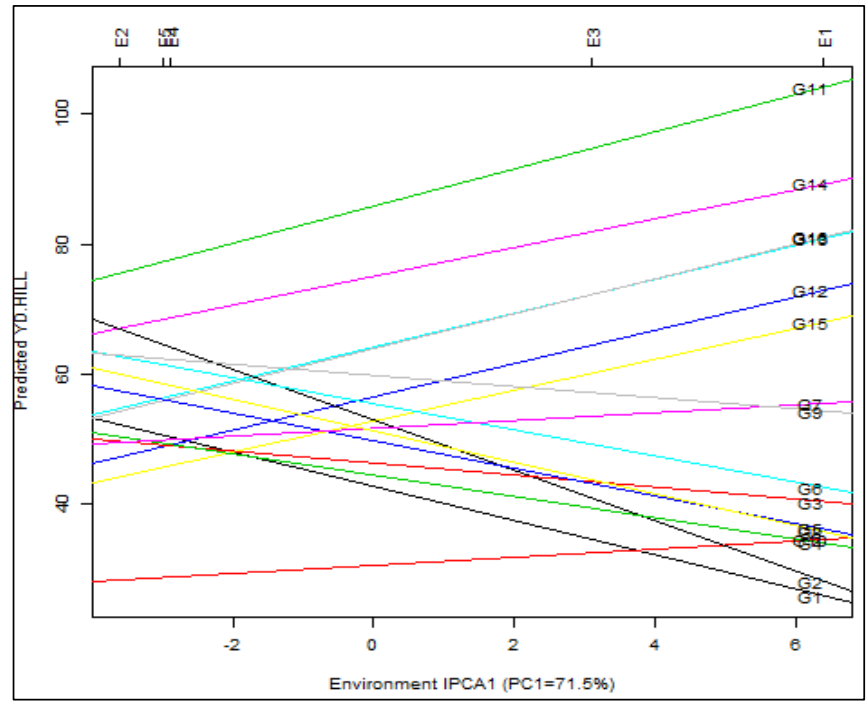

Fig-1: Adaptation map showing predicted grain yield across test environments 


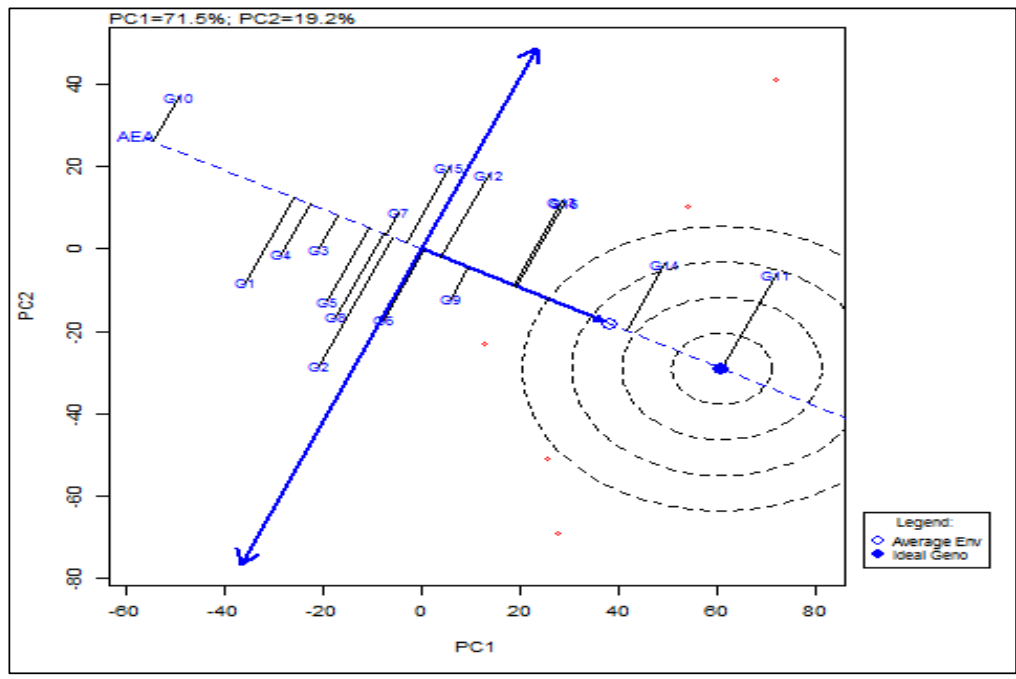

Fig- 2: Ranking genotypes based on both mean and stability relative to an ideal genotype.

\section{CONCLUSION}

The stability procedure used for evaluation of the genotypes showed that FARO 57 is the most stable genotype across the various locations and this was corrobated by Finlay-Wilkinson approach. NL 19 that is the most superior in terms of yield and stability is recommemnded for cultivation in Akure and Okitipupa environs. While, NL 34 and NL 25 for Akungba Akoko areas.

\section{REFERENCES}

1. Osekita, O. S. (2018). Genotype x Environment interaction and molecular diversity studies of selected rice (Oryza sativa L.) genotypes across three Nigerian agro-ecological zones. Ph.D Thesis of the Federal University of Technology, Akure Nigeria, 194.

2. Takahashi, K. (1984). Internode elongation of rice plants. VII. Hormonal control of internode growth of deep water rice . Japan Journal of Crop Science,53(2),160-161.

3. Ahn, S.W., Bonman, J.M., Bradon, D.M., Groth, D.E., Gunnel, P.S., Hibino, H., Holler, C.A., Lee, F.N., Mew, T.W., Prot, J.C., Rush, M.C., Shneider, R.W., Webster, R.K. and Whiitney, G. (1992). Compedium rice disease. Webster, R.K. and Gunnel, P.S. (Eds.) APS press.

4. Osekita, O. S., Akinyele, B.O. and Odiyi, A. C. (2015). Evaluation of exotic rice varieties for genetic parameters in a Nigerian agro-ecology. International Journal of Plant and Soil Science, 5(6), 350-358.

5. Chahal, G. S. and Gosal, S. S. (2002). Principles and procedures of plant breeding: Biotechnological and Conventional approaches. Narosa Publishing House. New Delhi, India.

6. Finlay, K. W. and Wilkinson, G. N. (1963). The analysis of adaptation in a plant breeding programme. Australian Journal of Agricultural Research,14, 742-754.

7. Yan, W., Kang, M. S., Ma, B., Woods, S. Cornelius, P. L. (2007). GGE biplot vs AMMI analysis of genotype-by-environment data. Crop Science, 47, $643-655$. 